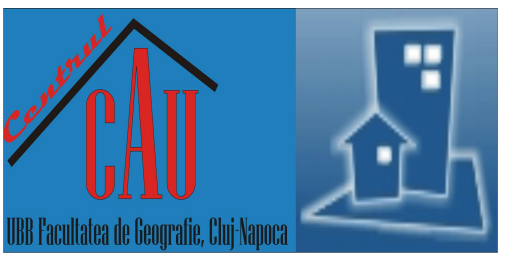

\title{
Characteristics of Residential Areas in Krakow Functional Urban Area
}

\author{
Piotr WĘGRZYNOWICZ ${ }^{* 1}$ \\ * Corresponding author \\ 1 Cracow University of Economics, College of Public Economy and Administration, Institute of Spatial Management and Urban \\ Studies, Department of Social-Economic Geography, Cracow, POLAND \\ $\triangle$ wegrzynp@uek.krakow.pl (i) https://orcid.org/oooo-ooo2-2133-6772 \\ DOI: 10.24193/JSSPSI.o3.CSPTER \\ https://doi.org/10.24193/JSSPSI.03.CSPTER
}

K e y w o r d s: urban transect method, housing development, Krakow Functional Urban Area, GIS analysis, urban sprawl, suburban area

\begin{abstract}
A B S T RACT
Urban sprawl is an unfavourable phenomenon not only in economic terms, but also due to the social and spatial effects. The failure to implement a coherent spatial policy in suburban areas may result in a chaotic distribution of residential buildings and cause spatial disorder. The main aim of this study is to present the classification of residential housing in the Krakow Functional Urban Area (FUA). Another objective of the study is to analyse the distribution of residential buildings in selected area. Moreover, it has been hypothesized that the chaotic suburbanization causes an uneven distribution of residential buildings in Krakow FUA. The urban transect method was selected to illustrate the spatial distribution of residential buildings in this area. Additionally, GIS analyses were performed based on official spatial data describing the location and type of residential buildings. Thanks to the combination of both methods, a classification of residential housing and its spatial distribution in Krakow FUA were presented. The analysis of the results obtained leads to the conclusion that the suburbanization process in Krakow FUA is characterized by a significant dominance of single-family housing. The result of chaotic suburbanization is also visible in the lack of developed general urban areas.
\end{abstract}

\section{INTRODUCTION}

The main context of the study is the progressive chaotic suburbanization in Polish cities, often identified with the urban sprawl process. This is the phenomenon of decentralization of residence and work places of the population to suburban local administrative units in relation to the core city, which eludes the control of the local spatial policy (Perrsky and Wiewel, 2012). This problem is not new; it was diagnosed in the 1930 s in the United States and was described by scattered development, low population density, and the dominant position of the car as a means of transport (Squires, 2002). Over the years, the rapid development of the automotive industry has strengthened urban sprawl, and researchers' interest has focused on the effects of this process, mostly landscape degradation or increase in infrastructure maintenance costs (Carruthers and Ulfarsson, 2003; Ewing, 1997; Gordon and Wong, 1985). Currently, the intensive development of suburban areas is a global issue (Wu and Phelps, 2011), while the difference between the traditional process of suburbanization and the urban sprawl phenomenon is visible (Hall, 1975). In Poland, as a post-socialist country, the development of suburban areas is characterized by different dynamics (Kovács et al., 2019) therefore it is worth mentioning the achievements of Polish researchers in this field.

The topic of suburban areas was raised in Poland for the first time in the 1950s, but the dominant 
theme in the debate was the function of food production for the needs of central cities (Kosiński, 1954; Krusze, 1954; Straszewicz, 1955). Over time, suburban areas have become increasingly multifunctional whilst agriculture ceased to play such a significant role. At that time, the research was focused on the changes in land use, morphology and physiognomy of the newlydeveloped settlements (Miszewska, 1985). Currently, the subject of suburban zones is a very popular issue in geography, and in addition to theoretical work related to the delimitation of these zones, the issue of costs associated with chaotic suburbanization is becoming increasingly important.

The Polish system of spatial planning, especially at the lowest administrative level, is ineffective in relation to the pressure on the creation of new housing developments (Lityński and Hołuj, 2017). Most new housing developments are based on administrative decisions that are not always in line with plans at a higher level. This phenomenon started to intensify after Poland's accession to the European Union in 2004 and is the result of several factors: the increase in the welfare of society, a greater availability of financial instruments (including mortgage loans) and the popularization of car transportation (Skóra and Węgrzynowicz, 2015). Studies on the costs of uncontrolled suburbanization were conducted; for instance, Śleszyński et al. (2020) estimated the annual losses of the Polish state budget resulting from spatial chaos at EUR 18 billion.

The issue of the development of suburban zones has been approached by researchers from many scientific disciplines. Various faces of the suburbanization process are presented in the studies by Lisowski and Grochowski (2009), Kajdanek (2012), Kaczmarek (2020) and Koj (2020). On the other hand, the consequences of suburbanization for cities and suburban areas around the world are analysed by Stelmaszewska (2020).

Currently, one of the main research trends in the subject of suburban zones is the measurement of the size and dynamics of the processes taking place there, e.g. urban sprawl. Some researchers use synthetic indicators for this purpose, for instance, Sudra (2016), Mantey and Pokojski (2020), but more and more often these studies are based on GIS analyses using available statistical and geospatial data (Ismael, 2021). Examples of the use of these methods are studies conducted for the city of Prishtina (Berila and Isufi, 2021) or for the city of Graz, in which data from the Corine Land Cover (CLC) Project was used (Steurer and Bayr, 2020).

To properly measure the urban sprawl process, it is necessary to recognize the typology of residential buildings built in suburban areas (Szmytkie, 2020). Lityński (2014, 2015, 2016) and Hołuj (2015a, 2015b) analysed the typology of housing development in suburban areas in Poland and indicated a lack of continuity of spatial development, i.e., leapfrog combined with a relatively low density of houses (Lityński and Hołuj, 2017). This article proposes a way of presenting the typology of residential buildings using the urban transect method. This method has become more and more popular in recent years, as evidenced by various research applications around the world (Ghorbanian, 2020; Bin Sulaiman and Almahmood,, 2021; Nizam, 2021; Han, 2021).

The urban transect method was selected to illustrate the classification of residential housing in Krakow Functional Urban Area, which is the main aim of this study. To increase its accuracy, in addition to the use of urban transect method, geospatial analyses were performed using official state geodetic data. The combination of these two methods allowed us to achieve the next objective of the study, which is to perform an analysis of the distribution of residential buildings in Krakow FUA and answer the research question: how does the type of residential buildings change with the distance from the centre of the Krakow FUA area? The conducted research also allowed us to prove the hypothesis that chaotic suburbanization causes an uneven distribution of residential housing in Krakow Functional Urban Area.

\section{THEORY AND METHODOLOGY}

The problem of urban sprawl goes beyond the administrative boundaries of cities; therefore a larger area, where the influence of the central city can be observed, should be selected for analysis. Relative to the Polish spatial planning policy, in the context of the impact on urban growth, there is a delimitation into Functional Urban Areas (FUA) (Lityński and Hołuj, 2020). Hence, the research area of this study was defined as the Krakow Functional Area (Krakow FUA), extending over $1275 \mathrm{~km}^{2}$, consisting of 15 communes, inhabited by over 1 million people (Fig. 1).

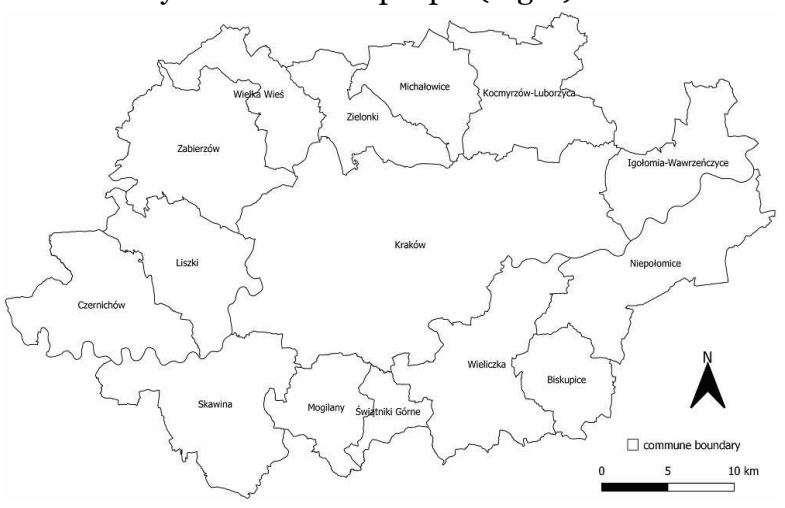

Fig. 1. Study area - Krakow FUA.

The selected space is a rapidly developing area (Krakow is the second largest city in Poland), characterized by a strong process of suburbanization, which generates a risk of chaotic development. The 
suburban area of Krakow is currently one of the most rapidly growing areas in the country also in terms of the spatial aspect, as a result of the influx of new inhabitants and the intensive construction traffic.

On the one hand, the proposed research area is artificially delimited, as it does not reflect the actual range of problems typical of suburban zones. On the other hand, the delimitation of the suburban area is not the main research topic, and the range of influence of the central city may only be greater than the ring of surrounding communes. Hence, the adopted delimitation should be treated as a limitation of the research area in which there is no risk of a lack of functional links with the core city.

Searching for a tool that offers a clear classification of city zones based on a morphological criterion (in the case of this study, it concerned the typology of housing development), it was decided to use the urban transect method.

Originally, the transect comes from the natural sciences, where it denotes a method of inventorying animate or inanimate elements of the natural environment through point observations along characteristic lines. It is an elongated research area that is most often used to register the diversity of the examined features in the environmental gradient. In the monitoring of natural habitats, the transect is designated to standardize and ensure the repeatability of field research methods in a homogeneous patch of natural habitat. Thus, the transect is not a representation but an exploration method that can lead to a variety of graphical or tabular representations.

The transect was introduced to urbanism as a planning tool at the turn of the $20^{\text {th }} / 21^{\text {st }}$ century by the American representatives of the New Urbanism (Duany and Talen, 2002). It is a method of inventorying elements of spatial development and spatial structure. It consists in carrying out observations at selected characteristic points on a straight or broken line, the opposite ends of which are in extremely different areas (Wróblewski, 2016). The urban transect serves both for the analysis of space and the organization of the built environment by dividing it into development zones. The zones describe the spectrum of the diversity of human habitats (Fig. 2), which stretches between the natural environment (zone T1) and the most densely urbanized space (zone T6). The areas that fall outside this characteristic are referred to as a special district (SD zone).

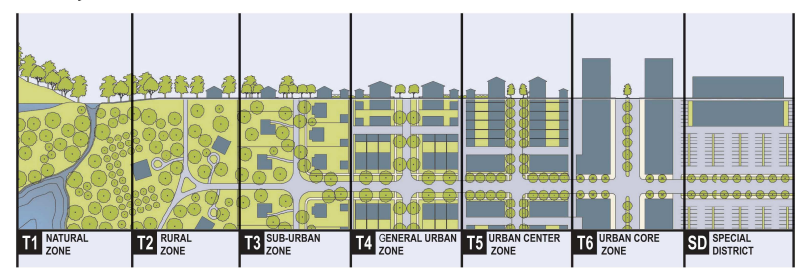

Fig. 2. Urban transect zoning (source: Centre for Applied Transect Studies).
The detailed characteristics of urban transect zoning are as follows (Duany et al, 2008):

- Zone T1 - natural - consists of areas close to or returning to their original state, including areas unsuitable for settlement;

- Zone T2 - rural - these are sparsely populated areas of open or arable land, namely represented by forests, arable land, pastures, and meadows; typical buildings here include farms, farm buildings, single-family houses, villas, and former mansions;

- Zone $\mathrm{T}_{3}$ - sub-urban - consists of residential areas of low intensity and partly mixed use; household work can be carried out in housing development, but there are also farm buildings related to crafts and small trades; plantings are naturalistic (free); the building line is significantly withdrawn; quarters can be large and the road network irregular;

- Zone T4 - general urban - consists of mixed use, but mainly residential urban fabric; there are mixed types of single-family and multi-family housing; building lines and street landscapes are variable;

- Zone $\mathrm{T}_{5}$ - urban centre - consists of high buildings density areas with mixed use; in addition to flats and apartments, a large number of retail trade services and offices are found here; a dense network of streets with wide sidewalks, planned tree plantings, and the line of buildings creates frontages or it is slightly withdrawn;

- Zone T6 - urban core - is the core of the city's identity with the highest buildings density and height of buildings, with the greatest variety of forms of use and public utility buildings of regional importance; the zone may have larger quarters, and the streets have regular plantings, wide sidewalks, and frontage buildings;

- SD zone - special district - monofunctional areas not having the features described above, e.g., industrial, commercial, and recreational areas.

Although the urban transect tool has a relatively short history of use, it is faced with criticism regarding, among other things, the subjective dimension of the observer's perception and the imposed zoning, which may be inadequate for cities outside the United States.

The representatives of the New Urbanism consider the criticism premature (Ellis, 2002) and emphasize the flexible form of urban transect, encouraging to apply adjustments to the tool in accordance with local conditions (Bohl and PlaterZyberk, 2006). The urban transect tool has gained increasing popularity all over the world, as evidenced by new research (Long et al., 2007; Talen, 2002; Volk and Zimmerman, 2002; Yu and Ng, 2007; Zhu et al., 2014) and changes in curricula at university studies outside the US (Wróblewski, 2016). 
In this study, the urban transect tool was used to present the classification of residential housing in the Krakow Functional Urban Area. To increase its accuracy, the open QGIS software was used to plan the routes of the transects. Using the Centroids function, the 'centre of gravity' of the Krakow FUA area was determined and routes in 16 directions were drawn from it, with observation points, every 500 meters. Thus, some 615 research points were created and inventoried in the field, based on which urban transect zones were assigned. The identification of individual zones was made in accordance with the previously mentioned descriptions. If a given point was in an inaccessible area due to natural conditions or administrative and legal factors, then the study was carried out in its closest vicinity. In particular situations, Google orthophoto map from 2019 was used. Thus, a mosaic of points marking various zones of the transect was created and will be discussed in detail in the next chapter.

Since the results of the study were not based only on field observations, the urban transect method was supplemented with GIS analysis. In this case, official data from the open access database of the Polish Central Office of Geodesy and Cartography were used to present the current situation of residential buildings in the research area. They were categorized into 4 types, as follows:

- single-family housing;

- semi-detached housing;

- multifamily housing;

- collective residence housing (e.g., dormitories, parish houses).

The above classification was analysed in terms of distribution within the communes components of the Krakow FUA; subsequently the distribution of different types of residential buildings was compared to the previously identified urban transect zones. For this purpose, circular buffers with a radius of $250 \mathrm{~m}$ were marked around the transect points (so that the buffers of subsequent points would not overlap) and the number and type of residential buildings contained in the individual buffers were verified. Based on these comparisons, the hypothesis presented in the introduction was proven and the main goal of the study was achieved.

\section{RESULTS AND DISCUSSION}

Figure 3 shows the results of the study conducted using the urban transect tool. Along the 16 routes, six main transect zones and special districts (SD) were identified at 615 research points.

It should be stated that Krakow FUA is an area where the metropolitan buildings (zone T6) are located only in the historical centre of the city of Krakow. Therefore, 38 research points were defined. Apart from a few exceptions, the metropolitan zone is adjacent to the urban zone. In the case of 84 research points, the site was recognised as $\mathrm{T}_{5}$ zone. In addition to the downtown area and large housing estates in Krakow, there are also satellite cities in the south such as Skawina and Wieliczka, marked as $\mathrm{T}_{5}$ zone. In 61 research sites, located mainly on the routes towards south, the development consistent with the description of the general urban zone (T4) was observed. The suburban area ( $\left.\mathrm{T}_{3}\right)$ is the most frequently noted type of development in the area under study, and 200 research points were marked in this respect. Some 109 points in the rural area (T2) were found located mainly on the outskirts of the studied area. The occurrence of the natural zone (T1) was observed in the case of 103 research points, and their distribution is very diverse, as it occurs both in the centre of the studied area and on its outskirts. Special districts (SD) were recorded only in 13 points, and they are mainly represented by vicinity of facilities such as: heat and power plant, sewage treatment plant or industrial and storage areas. Specialist districts appeared located only in the eastern part of the study area.

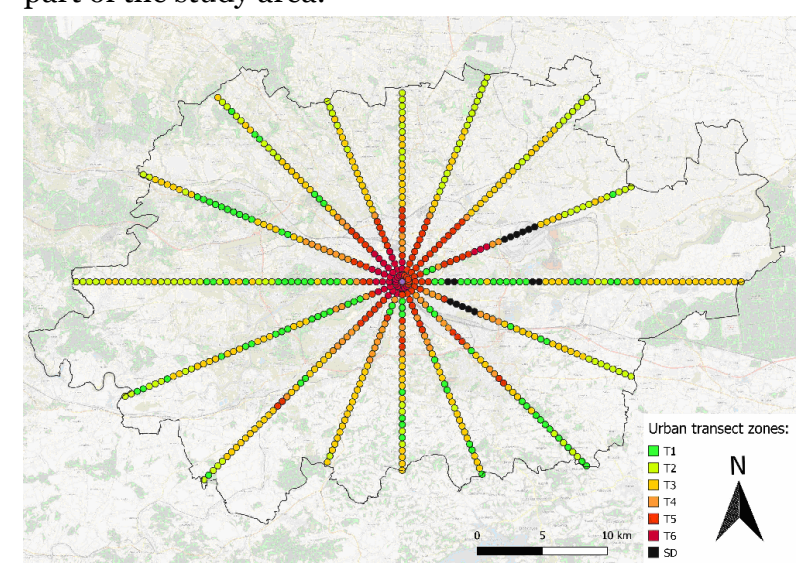

Fig. 3. Urban transect paths in Krakow FUA.

The research using the urban transect method shows Krakow FUA as an area diversified in terms of the typology of residential buildings with a strongly marked central city. However, approximately $32 \%$ of all research points were identified as a sub-urban zone, which may indicate the extensive suburbs surrounding the central city. Also GIS analysis was performed to present the structural classification of the residential buildings in Krakow FUA divided into 4 categories. The shapefile layer of buildings was elaborated based on data from the Database of Topographic Objects (BDOT10k) provided by the Central Office of Geodesy and Cartography. BDOT1ok is a spatial database with details corresponding to a topographic map on the scale 1:10 0oo. The layer of buildings was trimmed to the borders of Krakow FUA and a centroid was created in each of the objects. The composition containing the centroids of all residential buildings in Krakow FUA, is shown in Figure 4. 


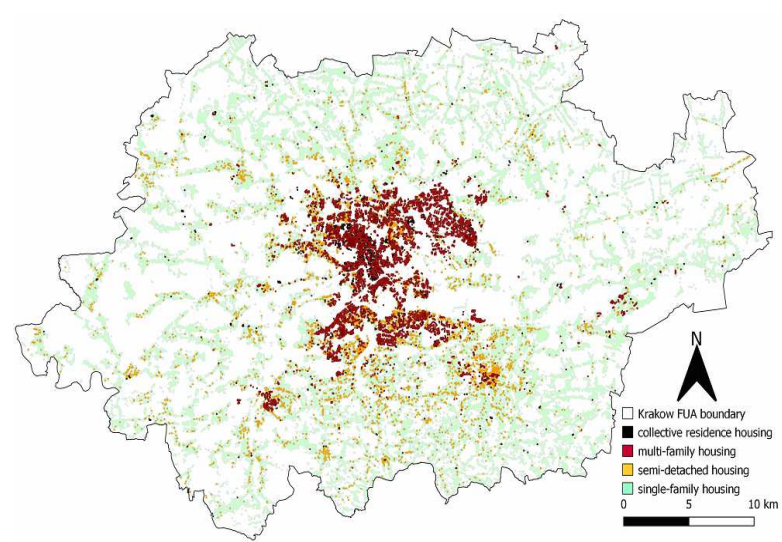

Fig. 4. Spatial distribution of residential buildings within Krakow FUA (source: own elaboration based on BDOT1ok data).
Figure 4 shows a high concentration of multifamily housing (buildings with 3 or more apartments) in the central part of Krakow FUA, particularly, in the city centre of Krakow. There are 14,028 multifamily buildings in the study area. A smaller share $(8,146)$ of objects is represented by semidetached houses, which are also located in the centre of the studied area but are not so highly concentrated. The largest number is recorded by the single-family buildings $(129,755)$ which dominate the rest of the surveyed area. There are 799 collective residence buildings, mainly located in the city of Krakow. Table 1 presents the number of individual types of buildings and their share in relation to all residential buildings by communes included in the Krakow FUA.

Table 1. Types of residential buildings in Krakow FUA communes.

\begin{tabular}{|c|c|c|c|c|c|c|c|c|c|c|}
\hline \multirow[t]{2}{*}{ Name of the commune } & \multicolumn{2}{|c|}{$\begin{array}{l}\text { Single-family } \\
\text { housing }\end{array}$} & \multicolumn{2}{|c|}{$\begin{array}{l}\text { Semi-detached } \\
\text { housing }\end{array}$} & \multicolumn{2}{|c|}{$\begin{array}{l}\text { Multi-family } \\
\text { housing }\end{array}$} & \multicolumn{2}{|c|}{$\begin{array}{l}\text { Collective } \\
\text { residence } \\
\text { housing }\end{array}$} & \multicolumn{2}{|c|}{$\begin{array}{l}\text { Number of all } \\
\text { residential } \\
\text { buildings }\end{array}$} \\
\hline & no. & $\%$ & no. & $\%$ & no. & $\%$ & no. & $\%$ & no. & $\%$ \\
\hline Biskupice & 3550 & 98.4 & 42 & 1.2 & 6 & 0.2 & 10 & 0.2 & 3608 & 100.0 \\
\hline Czernichów & 5095 & 96.0 & 205 & 3.9 & o & 0.0 & 7 & 0.1 & 5307 & 100.0 \\
\hline Igołomia-Wawrzeńczyce & 2325 & 96.9 & 63 & 2.6 & 5 & 0.2 & 7 & 0.3 & 2400 & 100.0 \\
\hline Kocmyrzów-Luborzyca & 5572 & 97.0 & 150 & 2.6 & 18 & 0.3 & 6 & 0.1 & 5746 & 100.0 \\
\hline Liszki & 5617 & 96.2 & 198 & 3.4 & 7 & 0.1 & 18 & 0.3 & 5840 & 100.0 \\
\hline Michałowice & 4231 & 97.0 & 119 & 2.7 & 10 & 0.2 & 4 & 0.1 & 4364 & 100.0 \\
\hline Mogilany & 4661 & 94.2 & 249 & 5.0 & 34 & 0.7 & 4 & 0.1 & 4948 & 100.0 \\
\hline Niepołomice & 9184 & 95.6 & 193 & 2.0 & 213 & 2.2 & 14 & 0.2 & 9604 & 100.0 \\
\hline Skawina & 8338 & 91.7 & 515 & 5.7 & 225 & 2.5 & 14 & 0.2 & 9092 & 100.0 \\
\hline Świątniki Górne & 3222 & 94.6 & 181 & $5 \cdot 3$ & 1 & 0.0 & 3 & 0.1 & 3407 & 100.0 \\
\hline Wieliczka & 16516 & 90.3 & 1450 & 7.9 & 294 & 1.6 & 30 & 0.2 & 18290 & 100.0 \\
\hline Wielka Wieś & 4712 & 95.5 & 206 & 4.2 & 8 & 0.2 & 7 & 0.1 & 4933 & 100.0 \\
\hline Zabierzów & 8651 & 95.6 & 315 & 3.5 & 40 & 0.4 & 42 & 0.5 & 9048 & 100.0 \\
\hline Zielonki & 7913 & $95 \cdot 5$ & 325 & 3.9 & 31 & 0.4 & 14 & 0.2 & 8283 & 100.0 \\
\hline Krakow (core city) & 40168 & 69.4 & 3935 & 6.8 & 13136 & 22.7 & 619 & 1.1 & 57858 & 100.0 \\
\hline
\end{tabular}

Table 1 and Figure 1 show the distribution of the residential buildings in the communes of Krakow FUA. We can note the dominance of single-family housing among other residential buildings in each of the municipalities in Krakow FUA. Their majority share is over $95 \%$ of the total number. In the central city of Krakow, the share of single-family houses is also high and amounts to $69.4 \%$. Apart from the core city, two other communes stand out, namely Skawina and Wieliczka, where the share of single-family buildings is about $90 \%$, and there is a greater share of semidetached buildings and multifamily buildings compared to other communes. These percentages indicate that Krakow is surrounded by communes dominated by single-family housing, typical for suburbanization processes. Among them, there are two towns that are more diversified in terms of the typology of residential buildings (Skawina, Wieliczka). It should also be noted that Krakow, despite being a central city, is also characterized by a large share of single-family housing. On the one hand, it is a result of the expansion of the city borders in the last century to the areas of former villages, where this type of development was common. On the other hand, it may indicate that the process of construction and settlement in the form typical for suburban zones begins already in the territory of the central city. To obtain a complete picture of the distribution of residential buildings in Krakow FUA, the number of individual types of buildings should be compared with the area of each commune (Table 2). 
Table 2. Types of residential buildings $/ \mathrm{km}^{2}$ in Krakow FUA communes.

\begin{tabular}{|c|c|c|c|c|c|}
\hline Name of the commune & $\begin{array}{l}\text { Single-family } \\
{\left[\text { housing } / \mathbf{k m}^{2}\right]}\end{array}$ & $\begin{array}{l}\text { Semi-detached } \\
\left.\text { [housing } / \mathbf{k m}^{2}\right]\end{array}$ & $\begin{array}{l}\text { Multi-family } \\
\text { [housing/(km²] }\end{array}$ & $\begin{array}{c}\text { Collective } \\
\text { residence } \\
{\left[\text { housing } / \mathbf{k m}^{2}\right]}\end{array}$ & $\begin{array}{l}\text { Area of the } \\
\text { commune } \\
{\left[\mathrm{km}^{2}\right]}\end{array}$ \\
\hline Biskupice & 86.3 & 1.0 & 0.1 & 0.2 & 41.135 \\
\hline Czernichów & 60.5 & 2.4 & 0.0 & 0.1 & 84.215 \\
\hline Igołomia-Wawrzeńczyce & 37.0 & 1.0 & 0.1 & 0.1 & 62.789 \\
\hline Kocmyrzów-Luborzyca & 67.2 & 1.8 & 0.2 & 0.1 & 82.92 \\
\hline Liszki & 77.9 & 2.7 & 0.1 & 0.2 & 72.066 \\
\hline Michałowice & 50.2 & 1.4 & 0.1 & 0.0 & 84.215 \\
\hline Mogilany & 106.6 & $5 \cdot 7$ & 0.8 & 0.1 & 43.709 \\
\hline Niepołomice & $95 \cdot 4$ & 2.0 & 2.2 & 0.1 & 96.292 \\
\hline Skawina & 83.5 & 5.2 & 2.3 & 0.1 & 99.831 \\
\hline Świątniki Górne & 158.4 & 8.9 & 0.0 & 0.1 & 20.345 \\
\hline Wieliczka & 165.7 & 14.5 & 2.9 & 0.3 & 99.676 \\
\hline Wielka Wieś & 97.6 & 4.3 & 0.2 & 0.1 & 48.273 \\
\hline Zabierzów & 87.0 & 3.2 & 0.4 & 0.4 & 99.409 \\
\hline Zielonki & 163.9 & 6.7 & 0.6 & 0.3 & 48.273 \\
\hline Krakow (core city) & 122.9 & 12.0 & 40.2 & 1.9 & 326.846 \\
\hline
\end{tabular}

In the communes of Zielonki, Wieliczka and Świątniki Górne there is a clear dominance of singlefamily housing, over 150 buildings $/ \mathrm{km}^{2}$ being recorded here. The highest density of semi-detached buildings is found in Wieliczka and Krakow (over 12 buildings $/ \mathrm{km}^{2}$ ), as well as in Świątniki Górne (8.9 buildings $/ \mathrm{km}^{2}$ ). In terms of multifamily housing, the central city - Krakow dominates (more than 40 buildings $/ \mathrm{km}^{2}$ ), and Niepołomice, Skawina, and Wieliczka also stand out from other communes (with more than 2 buildings $/ \mathrm{km}^{2}$ ). The list above confirms the location of collective residence housing mainly in Krakow (1.9 facilities $/ \mathrm{km}^{2}$ ).

The last phase of the analysis was to combine the results of the used methods. Buffers in the shape of a circle with a radius of $250 \mathrm{~m}$ were created around the transect points and the number and type of residential buildings contained in individual buffers were checked (Table 3).

In the analysis combining both methods used in this study, some 20,226 residential buildings were considered. The smallest number of residential buildings was found around the research points in the SD zone - only 20 facilities (mainly single-family houses). In the T1 (natural) and T2 (rural) zones, a few objects were also observed, and these were mainly single-family houses, fact that seems to confirm the characteristics of both zones. Moreover, two opposing trends can be observed. The percentage of single-family housing grows from the T6 urban core zone (4.2\%) to the rural zone T2 (97.2\%). In the opposite direction, there is an increase in the percentage share of multifamily housing. The semi-detached buildings are most visible in the general urban zone $\mathrm{T}_{4}$ (11.2\%). The collective residence buildings are mostly located in the $\mathrm{T} 5$ urban centre zone, and the $\mathrm{T} 6$ urban core zone, i.e., mainly in the city centre of Krakow.

The verification of the type of residential buildings in the vicinity of research points of the urban transect method in the vast majority confirms the correct selection of urban transect zones. The best justification for this statement is the aforementioned trends indicating increasing / decreasing the intensity of residential buildings along with the distance from the centre of the studied area. The graphic studies and tables presented in this chapter show the classification of residential housing in Krakow FUA and indicate the characteristics of the suburbanization process taking place here, which are: a significant domination of single-family housing in the vicinity of the central city and an increase in the intensity of residential development as we approach the city centre. Namely, single-family housing is the dominant form of residential building, regardless of the identified transect zones. On the one hand, it proves the character of Krakow (some researchers of Krakow's space define it as - the city of small towns (Ziobrowski, 1996)), but on the other hand, it illustrates the process of strong suburbanization that begins in the central city. The effect of this phenomenon is a poorly developed general urban zone [T4] in the south or it is completely absent in the north and east. In these zones, the share of semidetached buildings is high, which is characteristic of the urban sprawl process (it allows investors to achieve higher profits than in the case of single-family housing). Apart from the central city and satellite cities, the most frequently identified zones were the interpenetrating rural and sub-urban zones. 


\section{Characteristics of Residential Areas in Krakow Functional Urban Area \\ Journal of Settlements and Spatial Planning, Special Issue, (2022) 15-24 \\ Cities, Suburbs and Peripheries in Theory and Empirical Research}

Looking at the communes where this phenomenon occurs and comparing it with the density of types of residential buildings $/ \mathrm{km}^{2}$, it can be concluded that single-family housing is entering areas that were previously only used for agriculture. This conclusion relates to research conducted by Polish researchers in the 1950s and onward (Krusze, 1954; Straszewicz, 1955; Lityński, 2014). The urban transect theory shows that the optimal spatial layout of buildings is concentric and zonal. Starting from the urban core area, the intensity of development gradually decreases to the rural area.

Table 3. Types of residential buildings divided into urban transect zones.

\begin{tabular}{|c|c|c|c|c|c|c|c|c|c|c|}
\hline \multirow{2}{*}{$\begin{array}{l}\text { Urban } \\
\text { transect } \\
\text { zoning }\end{array}$} & \multicolumn{2}{|c|}{$\begin{array}{l}\text { Single-family } \\
\text { housing }\end{array}$} & \multicolumn{2}{|c|}{$\begin{array}{l}\text { Semi-detached } \\
\text { housing }\end{array}$} & \multicolumn{2}{|c|}{$\begin{array}{l}\text { Multi-family } \\
\text { housing }\end{array}$} & \multicolumn{2}{|c|}{$\begin{array}{l}\text { Collective } \\
\text { residence housing }\end{array}$} & \multicolumn{2}{|c|}{$\begin{array}{l}\text { Number of all } \\
\text { residence housing }\end{array}$} \\
\hline & no. & $\%$ & no. & $\%$ & no. & $\%$ & no. & $\%$ & no. & $\%$ \\
\hline $\mathrm{T} 1$ & 611 & 88.7 & 34 & 4.9 & 43 & 6.2 & 1 & 0.1 & 689 & 100.0 \\
\hline $\mathrm{T} 2$ & 770 & 97.2 & 22 & 2.8 & $\mathrm{O}$ & 0.0 & $\mathrm{O}$ & 0.0 & 792 & 100.0 \\
\hline $\mathrm{T}_{3}$ & 7564 & 92.8 & 481 & 5.9 & 90 & 1.1 & 12 & 0.2 & 8147 & 100.0 \\
\hline $\mathrm{T}_{4}$ & 3327 & 74.5 & 501 & 11.2 & 605 & 13.6 & 31 & 0.7 & 4464 & 100.0 \\
\hline $\mathrm{T}_{5}$ & 1642 & 43.9 & 293 & 7.8 & 1719 & $45 \cdot 9$ & 90 & 2.4 & 3744 & 100.0 \\
\hline T6 & 99 & 4.2 & 19 & 0.8 & 2158 & 91.1 & 94 & 3.9 & 2370 & 100.0 \\
\hline SD & 18 & 90.0 & 2 & 10.0 & 0 & 0.0 & o & 0.0 & 20 & 100.0 \\
\hline
\end{tabular}

Leaving aside the issue of the location of the T1 zone, which is largely the result of natural conditions and SD zones, in the area under study, there is a discontinuity in the sequence of zones (in particular, the absence or a small share of the $\mathrm{T} 4$ zone). A significant advantage is also visible in the presence of $\mathrm{T}_{2}$ and $\mathrm{T}_{3}$ zones, where the type of residential buildings is typical for the suburbanization process. It can be concluded that the suburbanization process affects the distribution of residential housing in Krakow FUA. This influence may have a negative dimension on the perception of the "urbanity" of the studied area, analysed according to the intensity of housing development. When answering the research question posed in this article, it should be stated that high-intensity residential development zones are located in the centre of the area and most often adjacent to low-intensity residential zones. The process of suburbanization, which begins within the borders of the central city, resulted in the lack of development of zones with an medium intensity of residential buildings ( $\mathrm{T}_{4}$ - general urban zone), and thus disturbs the concentric system of zones. The dominance of single-family housing in the entire area of Krakow FUA may also affect the perception of the research area as a smaller urban centre than it really is.

The urban transect method used in this study is only gaining in popularity, and examples of its use mainly concern cities in the USA. In Poland, the most similar research was carried out by Wróblewski for the city of Łódź (2016), where the transect paths were also marked out and then the transect zones were assigned to research points. However, it was used to determine the development of various city zones with regard to transport accessibility to public facilities, and it was also supported by GIS analyses. The use of zoning in the transect method in terms of the type of residential development is important due to the clarity of the perception of urban space. It allows to assess whether the city is developing in an orderly, concentric manner, and the intensity of spatial development increases with the approach to the centre.

This method has its limitations. It does not cover the entire area, but only the closest vicinity of research points. It is based on the subjective perception of the observer / researcher, even though they use a unified description (code) of zoning for interpretation. On the other hand, the urban transect method takes into account the direct experience of the studied space, which would be impossible to achieve only with GIS analysis. However, the use of GIS analyses was necessary to confirm the observations resulting from the urban transect method.

The value of the study will certainly be greater if it is repeated in a few years, which will allow us to verify the observations made considering the time factor. One of these observations was related to the underdeveloped general urban zone, which may be taken a suggestion for local planners to emphasize the importance of intensive housing development in shaping the city and integrate this matter in the elaboration of regulations.

\section{CONCLUSIONS}

It should be emphasized that thanks to the combination of the two methods (urban transect and 
GIS analysis), it was possible to fully achieve the main goal of the study, mainly to present the classification of residential housing in Krakow FUA. An analysis of the distribution of residential buildings was also performed, which allowed us to answer the research question about how the type of residential buildings is changing in Krakow FUA. The following observations have been made on this topic. The results of the study, presented both at the commune level and in a holistic approach, provide the opportunity to observe the strong process of suburbanization resulting in the dominance of singlefamily housing in each of the communes of Krakow FUA, including the central city. The consequence of this poorly developed general urban area or its complete absence. Single-family and semi-detached housing extends over areas that were previously used for agriculture, and the boundaries between the rural and suburban zones are no longer visible. It can therefore be concluded that the chaotic suburbanization causes an uneven distribution of residential buildings in Krakow FUA. The results of the study may be useful for local planners who, by creating legal regulations, may influence the development of buildings. The desired action is the creation of zones with greater intensity of residential development replacing single-family housing, which is the result of the suburbanization process starting already within the borders of the central city. This action will allow to reduce infrastructure and social costs in the long term for the entire Krakow FUA. The course of the study may also be interesting for researchers looking for new research methods. An additional goal to be achieved by this study is to popularize the urban transect method as a research tool for space exploration. At the same time, it is worth noting that the support of additional analyses (e.g., spatial data analysis) may facilitate the implementation of the main research assumptions and make the study more valuable.

\section{ACKNOWLEDGEMENTS}

The publication was financed from the subsidy granted to the Cracow University of Economics.

\section{REFERENCES}

Berila A., Isufi F. (2021), Two Decades (2000-2020) Measuring Urban Sprawl Using GIS, RS and Landscape Metrics: a Case Study of Municipality of Prishtina (Kosovo). Journal of Ecological Engineering. DOI: 10.12911/22998993/137078

Bin Sulaiman F., Almahmood M. (2021), Following the process: unfolding how form-based code-as a travelling concept-has been adapted within the social, cultural, and architectural context of Riyadh. Urban Design International. DOI: 10.1057/s41289-021oo163-9
Bohl Ch. C., Plater-Zyberk E. (2006), Building Community across the Rural-to-Urban Transect. Places 18(1), 4-17.

URL: https://escholarship.org/uc/item/1zt6gosr

Carruthers J. I., Ulfarsson G. F. (2003), Urban sprawl and the cost of public services, Environment and Planning B, 30(4), 503-522.

DOI: https://doi.org/10.1068/b12847

Centre for Applied Transect Studies (2021), The Transect. URL: https://transect.org/transect.html. Accessed on 30.09.2021

Duany A., Talen E. (2002), Transect planning. Journal of the American Planning Association 68(3), 245-266.

DOI: https://doi.org/10.108o/01944360208976271

Duany A., Sorlien S., Wright W. (2008), SmartCode Version 9. New Urban News Publications. ISBN: 0974502154

Ellis C. (2002), The New Urbanism: Critiques and Rebuttals. Journal of Urban Design, 7(3), 261-291. DOI: https://doi.org/10.1080/1357480022000039330

Ewing R. (1997), Is Los Angeles-style sprawl desirable? Journal of the American Planning Association, 63(1), 107-126.

DOI: https://doi.org/10.108o/01944369708975728

Ghorbanian M. (2020), The Evolution of Urban Zoning from Conventional to Form Based Codes Introducing Non-Euclidean Zoning Techniques. International Journal of Architecture and Urban Planning. DOI: 10.22068/ijaup.30.1.107

Gordon P., Wong H. L. (1985), The Costs of Urban Sprawl: Some New Evidence. Environment and Planning A, 17(5), 661-666.

DOI: https://doi.org/10.1068/a170661

Hall P. (1975), Urban and Regional Planning. Pelican. Harmondsworth

Han S. (2021), The use of transects for resilient design: core theories and contemporary projects. Landscape Ecology, 36, 1567-1582. DOI: 10.1007/s10980-02O01172-9

Hołuj A. (2015a), Challenges of local self-government in terms of progressive depreciation of space as a result of the urban sprawl, proposing a methodology for optimal delimitation of areas. Culture and Politics (ed.) C. Calm, European Higher School for them. Fr. J. Tischnera

Hołuj A. (2015b), Selected aspect of development management in the areas affected by urban sprawl process in Poland. Public Management. Scientific Journal of the Institute of Public Affairs of the Jagiellonian University, 1 (29)

Ismael H. M. (2021), Urban form study: the sprawling city - review of methods of studying urban sprawl. GeoJournal, 86, 1785-1796. DOI: 10.1007/s10708-02010157-9

Kaczmarek T. (2020), Różne oblicza suburbanizacji. Od przedmieść w cieniu miasta do post-suburbiów 
(Various faces of suburbanization. From suburbs in the shadow of the city to the post-suburbs), Prace i Studia Geograficzne 65(3), 103-113.

URL: https://wgsr.uw.edu.pl/wgsr/wpcontent/uploads/2020/07/103-113_T_Kaczmarek.pdf

Kajdanek K. (2012), Suburbanizacja po polsku (Suburbanization in Poland), Wydawnictwo NOMOS, Krakow. [Book in Polish]. ISBN 978-83-7688-107-2

Koj J. (2020), Rozwój przedmieść a globalizacja: zróżnicowanie przebiegu procesów suburbanizacji na świecie i w Polsce (Suburban development and globalization: diversity of suburbanization processes worldwide and in Poland). Urban Development Issues, 66, 15-23. DOI: 10.2478/udi-2020-0007

Kosiński L. (1954), Funkcja rolnicza strefy podmiejskiej (Agricultural function of the suburban area), Przegląd Geograficzny 26(4), 170-181

Kovács Z., Farkas Z. J., Egedy T., Kondor A. C., Szabó B., Lennert J., Kohán B. (2019), Urban sprawl and land conversion in post-socialist cities: The case of metropolitan Budapest. Cities, 92, 71-81. DOI: https://doi.org/10.1016/j.cities.2019.03.018

Krusze N. (1954), Niektóre problemy zaopatrzenia miasta w żywność (Some problems with the city's food supply), Miasto, 3

Lisowski A., Grochowski M. (2009), Procesy suburbanizacji. Uwarunkowania, formy, konsekwencje (Suburbanization processes. Determinants, forms, consequences). In: Saganowski K., ZagrzejewskaFiedorowicz M., Zuber P. (eds), Ekspertyzy do Koncepcji Przestrzennego Zagospodarowania Kraju 2008-2033. Ministerstwo Rozwoju Regionalnego, Warszawa, 221-280. ISBN: 9788376100722 8376100726

Lityński P. (2014), Ekonomiczne konsekwencje przestrzennej decentralizacji i centralizacji miasta na podstawie literatury zagranicznej (The Economic Consequences of Urban Decentralisation and Centralisation in the Light of Foreign Literature). Cracow Review of Economics and Management, 12(936), 45-61. [Article in Polish].

URL: https://zeszyty-

naukowe.uek.krakow.pl/article/view/673

Lityński P. (2015), Degree and Features of Urban Sprawl in Selected the Biggest Polish Cities. Research Papers of Wroclaw University of Economics, 402, 184193. DOI: $10.15611 / \mathrm{pn} .2015 .402 .18$

Lityński P. (2016), The correlation between urban sprawl and the local economy in Poland. Urbani Izziv, 27(2), 8696. DOI: 10.5379/urbani-izziv-en-2016-27-02-001

Lityński P., Hołuj A. (2017), Urban Sprawl Costs: The Valuation of Households' Losses in Poland, Journal of Settlements and Spatial Planning, 8(1), 11-35. DOI: 10.24193/JSSP.2017.1.02

Lityński P., Hołuj A. (2020), Urban Sprawl Risk Delimitation: The Concept for Spatial Planning Policy in Poland. Sustainability, 12(7), 2637.
DOI: https://doi.org/10.3390/su12072637

Long H., Heilig G. H., Li X., Zhang M. (2007), Socio-economic development and land-use change: Analysis of rural housing land transition in the Transect of the Yangtse River, China. Land Use Policy, 24(1), 141153.

DOI: https://doi.org/10.1016/j.landusepol.2005.11.003

Mantey D., Pokojski W. (2020), New Indicators of Spatial Chaos in the Context of the Need for Retrofitting Suburbs, Land, 9(8), 276.

DOI: https://doi.org/10.3390/land9080276

Miszewska B. (1985), Przemiany morfologiczne osadnictwa wiejskiego w strefie podmiejskiej Wrocławia. Metody analizy (Morphological changes in rural settlement in the suburbs of Wrocław. Analysis methods). Acta Universitatis Lodziensis, Folia Geographica, 5, 103-122

Nizam F. (2021), Transect urbanism and form-based codes. In: Petrişor A. I., Meita V. (Eds), Paper proceedings of the research conference on constructions, economy of constructions, architecture, urbanism and territorial development, INCD URBANINCERC, 5-10. ISSN: 2393-3208. URL: https://www.ceeol.com/search/book-detail ?id=949013 Perrsky J., Wiewel J. (2012), Urban Decentralization, Suburbanization, and Sprawl: An Equity Perspective. In: N. Brooks, K. Donaghy, G. J. Knaap (eds.), Urban Economics and Planning, Oxford University Press, New York.

DOI: 10.1093/oxfordhb/9780195380620.013.0008

Squires G. D. B. (2002), Urban Sprawl: Causes, Consequences and Policy Responses, Urban Institute Press, Washington D.C. ISBN: 978-087-76-6709-4

Skóra K., Węgrzynowicz P. (2015), Ocena rozwoju zrównoważonego transport w Krakowie (Evaluation of the development of sustainable transport in Cracow). In Śliwa M. (ed.) $3 \mathrm{Z}$ Miasta: Zauważ-ZrównoważZagospodaruj, Opole University Publishing House [Book in Polish]. 95-104

Stelmaszewska N. (2020), Konsekwencje suburbanizacji dla miast i stref podmiejskich w świetle literatury krajowej i zagranicznej (The consequences of suburbanization for cities and suburban areas in the light of national and foreign literature), Urban Development Issues, 66(1), 25-34. DOI: 10.2478/udi-2020-0008

Steurer M., Bayr C. (2020), Measuring urban sprawl using land use data. Land Use Policy, 97, 104799. DOI: https://doi.org/10.1016/j.landusepol.2020.104799

Straszewicz L. (1955), Strefa podmiejska jako problem, urbanistyczny (The suburban area as an urban problem), Miasto, 12

Sudra P. (2016), Zastosowanie wskaźników koncentracji przestrzennej w badaniu procesów urban sprawl (The use of spatial concentration indicators in the study of urban sprawl processes). Przegląd Geograficzny, 88(2), 247-272.

DOI: 10.7163/PrzG.2016.2.6 
Szmytkie R. (2020), The impact of residential suburbanization on changes in the morphology of villages in the suburban area of Wrocław, Poland. Environmental \& Socio-economic Studies, 8(4), 24-43. DOI: https://doi.org/10.2478/environ-2020-0021

Śleszyński P., Kowalewski A., Markowski T., Legutko-Kobus P., Nowak M. (2020), The Contemporary Economic Costs of Spatial Chaos: Evidence from Poland. Land, 9(7), 214. DOI: https://doi.org/10.3390/land9070214

Talen E. (2002), Help for Urban Planning: The Transect Strategy. Journal of Urban Design, 7(3), 293-312. DOI: https://doi.org/10.1080/1357480022000039349

Volk L., Zimmerman T. (2002), American Households on (and off) the Urban-to-rural Transect. Journal of Urban Design, 7(3), 341-352. DOI: https://doi.org/10.1080/1357480022000039376

Wróblewski W. (2016), Transekt urbanistyczny w dydaktyce Gospodarki Przestrzennej (Urban Transect in Didactics of Spatial Planning). In: Chmielewski J. M. (ed.), Projektowanie urbanistyczne na kierunku Gospodarka Przestrzenna, Politechnika Warszawska, Warszawa. ISBN: 978-83-7814-584-4. [Book in Polish], 68-82

Wróblewski W. (2016), Wykorzystanie narzędzi Nowego Urbanizmu $\mathrm{w}$ procesie powrotu Łodzi do
Centrum (Using the tools of New Urbanism in the process of Łódź's return to the Center). In: Markowski T. (ed.), Powrót do centrum miasta - wyzwania dla krajowej polityki miejskiej, Studia Komitetu Przestrzennego Zagospodarowania Kraju PAN tom CLXVIII, [Book in Polish], 136-157

Wu F., Phelps N. A. (2011), (Post)suburban development and state enterpreneuralism in Beijing's outer suburbs. Environment and Planning A, 43(2), 410-430. DOI: https://doi.org/10.1068/a43125

Yu X. J., Ng C. N. (2007), Spatial and temporal dynamics of urban sprawl along two urban-rural transects: A case study of Guangzhou, China. Landscape and Urban Planning, 79(1), 96-109. DOI: https://doi.org/10.1016/j.landurbplan.2006.03.008

Zhu F., Zhang F., Li C., Zhu T. (2014), Functional transition of the rural settlement: Analysis of land-use differentiation in a transect of Beijing, China. Habitat International, $41, \quad 262-271 . \quad$ DOI: https://doi.org/10.1016/j.habitatint.2013.07.011

Ziobrowski Z. (1996), Plany rozwoju Krakowa - ich uwarunkowania I efekty przestrzenno-funkcjonalne (Plans of the development of Cracow - their conditions and spatio-functional effects), Folia Geographica, Series Geographica-Oeconomica, 27, 297-308 